\title{
Effects of Tityus stigmurus (Thorell 1876) (Scorpiones: Buthidae) venom in isolated perfused rat kidneys
}

\author{
NATHALIAA. SILVA ${ }^{1}$, CLEIDE M.R. ALBUQUERQUE ${ }^{1}$, ALINE D. MARINHO ${ }^{2}$, ROBERTA J.B. JORGE ${ }^{2}$, ANTONIO G. \\ SILVA NETO ${ }^{2}$, HELENA S.A. MONTEIRO ${ }^{2}$, TÚLIO D. SILVA ${ }^{3}$, MÁRCIA V. SILVA ${ }^{3}$, MARIA TEREZA S. CORREIA ${ }^{3}$, TICIANA \\ P. PEREIRA ${ }^{4}$, ALICE M.C. MARTINS ${ }^{4}$, DALGIMAR B. MENEZES ${ }^{5}$, RAFAEL M. XIMENES ${ }^{6}$ and RENÉ D. MARTINS ${ }^{7}$ \\ ${ }^{1}$ Departamento de Zoologia, Centro de Ciências Biológicas, Universidade Federal de \\ Pernambuco, Av. Professor Moraes Rego, s/n, 50670-420 Recife, PE, Brasil \\ ${ }^{2}$ Departamento de Fisiologia e Farmacologia, Faculdade de Medicina, Av. Cel. Nunes de Melo, 1127, 60430-270 Fortaleza, CE, Brasil \\ ${ }^{3}$ Departamento de Bioquímica, Centro de Ciências Biológicas, Universidade Federal de \\ Pernambuco, Av. Professor Moraes Rego, s/n, 50670-420 Recife, PE, Brasil \\ ${ }^{4}$ Departamento de Análises Clínicas e Toxicológicas, Faculdade de Farmácia, Odontologia e Enfermagem, \\ Universidade Federal do Ceará, Rua Capitão Francisco Pedro, 1210, 60430-370 Fortaleza, CE, Brasil \\ ${ }^{5}$ Departamento de Patologia e Medicina Legal, Faculdade de Medicina, Universidade Federal \\ do Ceará, Rua Monsenhor Furtado, s/n, 60441-750 Fortaleza, CE, Brasil \\ ${ }^{6}$ Departamento de Antibióticos, Centro de Ciências Biológicas, Universidade Federal de \\ Pernambuco, Rua Professor Artur de Sá, s/n, 50740-520, Recife, PE, Brasil \\ ${ }^{7}$ Centro Acadêmico de Vitória, Universidade Federal de Pernambuco, Rua Alto do \\ Reservatório, s/n, 55608-680 Vitória de Santo Antão, PE, Brasil
}

Manuscript received on April 15, 2015; accepted for publication on June 24, 2015

\begin{abstract}
Scorpions belonging to the Tityus genus are of medical interest in Brazil. Among them, Tityus stigmurus is the main scorpion responsible for stings in the Northeast region. After a sting, the scorpion venom distributes rapidly to the organs, reaching the kidneys quickly. However, there are few studies concerning the renal pathophysiology of scorpion poisoning. In this study, we evaluated the effects of T. stigmurus venom $(\mathrm{TsV})$ on renal parameters in isolated rat kidneys. Wistar rats $(\mathrm{n}=6)$, weighing 250-300 g, were perfused with Krebs-Henseleit solution containing $6 \mathrm{~g} / 100 \mathrm{~mL}$ bovine serum albumin. TsV at 0.3 and 1.0 $\mu \mathrm{g} / \mathrm{mL}$ was tested, and the effects on perfusion pressure (PP), renal vascular resistance (RVR), urinary flow (UF), glomerular filtration rate (GFR), and electrolyte excretion were analyzed. Effects were observed only at TsV concentration of $1.0 \mu \mathrm{g} / \mathrm{mL}$, which increased $\mathrm{PP}\left({ }_{\text {control }} \mathrm{PP}_{40}=92.7 \pm 1.95 ;{ }_{\mathrm{TsV}} \mathrm{PP}_{40}{ }^{\circ}=182.0 \pm\right.$ $\left.4.70^{*} \mathrm{mmHg},{ }^{*} \mathrm{p}<0.05\right), \mathrm{RVR}\left({ }_{\text {control }} \mathrm{RVR}_{40}=3.28 \pm 0.23 \mathrm{mmHg}{ }_{\mathrm{Tst}} \mathrm{RVR}_{40}=6.76 \pm 0.45^{*} \mathrm{mmHg},{ }^{*} \mathrm{p}<0.05\right.$ ), $\mathrm{UF}\left(_{\text {control }} \mathrm{UF}_{50}=0.16 \pm 0.04{ }_{\mathrm{Tst}} \mathrm{UF}_{50}=0.60 \pm 0.10^{*} \mathrm{~mL} / \mathrm{g} / \mathrm{min},{ }^{*} \mathrm{p}<0.05\right)$, GFR and electrolyte excretion, with histological changes that indicate renal tubular injury. In conclusion, T. stigmurus venom induces a transient increase in PP with tubular injury, both of which lead to an augmented electrolyte excretion.
\end{abstract}

Key words: 2D-PAGE, kidney, MDCK, venom, Tityus stigmurus.

\section{INTRODUCTION}

Scorpion stings are the second most frequent cause of poisoning by venomous animals in humans worldwide (Chippaux and Goyffon 2008).

Correspondence to: Rafael Matos Ximenes

E-mail: rafael.ximenes@ufpe.br
In Brazil, scorpion poisoning is a serious public health issue owing to the increase in number of victim notifications, which rose from 12,704 cases in 2000 to 69,053 cases in 2013 (Brasil 2014). The clinical symptoms of scorpion poisoning are due to the presence of neurotoxic peptides in the venom (Possani et al. 1999, Rodriguez De La Vega and 
Possani 2005, Batista et al. 2007), which cause disturbances in the nervous, cardiovascular and muscular systems (Abroug et al. 1995, Zeghal et al. 2000, Mazzei de D'Avila et al. 2002).

Scorpions from the genus Tityus, mainly $T$. serrulatus, T. bahiensis, and T. stigmurus, are responsible for most of the severe poisoning cases in Brazil (Fundação Nacional de Saúde 2001). T. stigmurus is the main scorpion responsible for poisoning particularly in the Northeast region, where the species is found (Brasil 2012). Scorpion venoms are composed of mucus, mucopolysacharides, oligopeptides, nucleotides, protease inhibitors, histamine releasers, amino acids, enzymes (hyaluronidases and metalloproteases), and lipids. Several low molecular weight basic proteins (neurotoxins) and bioactive amines (serotonin and histamine) also are present in scorpion venoms, including Tityus venom, and act on ion channels in biological membranes (Possani 1984, Gwee et al. 2002, Vasconcelos et al. 2005).

Experimental studies in rats showed hemorrhage and congestion in kidney tissue, causing acute renal failure (Dehghani and Fathi 2012), mainly in young animals, after the administration of T. serrulatus venom (Nunan et al. 2003). Moreover, Alves et al. (2005) showed that T. serrulatus venom altered renal function parameters by increasing perfusion pressure (PP) and renal vascular resistance (RVR) in the isolated perfused kidney assay.

Although nephrotoxicity is one of the most dangerous and life-threatening effects of animal venoms (Berger et al. 2012, Viswanathan and Prabhu 2011), few studies have shown the renal pathophysiology of scorpionism. Acute renal failure in humans after Hemiscorpius lepturus stings has been reported in Pakistan and Iran (Naqvi et al. 1998, Valavi and Ansari 2008). In Brazil, changes in serum levels of creatinine and urea after $T$. serrulatus stings in humans have also been reported, indicating the possible kidney damage caused by the venom toxins (Nunan et al. 2003).
The clinical aspects of $T$. stigmurus stings may vary from mild (with local edema and pain as the main clinical symptoms), moderate (with nausea, vomiting, sweating, salivation, agitation, tachycardia and tachypnea) to severe cases (with profuse vomiting, sweating and salivation, prostration, seizures, pulmonary edema, and shock) (Fundação Nacional de Saúde 2001). However, there is little information about the renal effects of this venom. Thus, this work aimed to evaluate the effects of T. stigmurus venom on the renal function of rats, through examination of parameters such as perfusion pressure (PP), renal vascular resistance (RVR), urinary flow (UF), glomerular filtration rate (GFR), and the electrolyte excretion of sodium, potassium, and chloride. Protein analysis was conducted by gel electrophoresis (2D-PAGE), and the direct effect of the venom in kidney epithelial tubular cells in culture also was evaluated.

\section{MATERIALS AND METHODS}

\section{VENOM EXTRACTION AND PROTEIN QUANTIFICATION}

Tityus stigmurus venom (TsV) was milked from 98 adult scorpions collected in the city of Vitória de Santo Antão (08 $\left.07^{\circ} 05^{\prime \prime} \mathrm{S} ; 35^{\circ} 17^{\prime} 29^{\prime \prime} \mathrm{W}\right), 47.2$ $\mathrm{Km}$ from Recife/PE. Before venom extraction, the scorpions were fasted for one week. Venom extraction was carried out using an electric stimulus of $30 \mathrm{~V}$ in the telson to release the venom, which was collected in a capillary tube. The venom was pooled, freeze dried and stored at $-20{ }^{\circ} \mathrm{C}$ until use.

Protein concentrations were determined using a commercial protein colorimetric assay kit, 2D Quant Kit, according to the manufacturer protocol (GE Healthcare Life Sciences ${ }^{\circledR}$, PA, USA) with bovine serum albumin (BSA) as a standard of measurement and absorbance at $480 \mathrm{~nm}$.

PROTEIN ANALYSIS BY GEL ELECTROPHORESIS (2D-PAGE)

Protein samples $(400 \mu \mathrm{g})$ were dissolved in 250 $\mu \mathrm{L}$ of rehydration buffer ( $8 \mathrm{M}$ urea, $2 \% \mathrm{w} / \mathrm{v}$ 
3-[(3-cholamidopropyl)dimethylammonio]-1propanesulfonate (CHAPS), $20 \mathrm{mM}$ dithiothreitol (DTT), $0.5 \%$ immobilized $\mathrm{pH}$ gradient (IPG) buffer, and $0.002 \%$ bromophenol blue) and were loaded onto IPG strips $(13 \mathrm{~cm}$ with a linear range of IPG pH 3-10) after a brief sonication and centrifugation. Isoelectric focusing was performed in the Ettan IPGphor isoelectric focusing system according to the manufacturer protocol. Before running the two- dimensional electrophoresis, the IPG strips were equilibrated, first for $15 \mathrm{~min}$ in fresh buffer (6 M urea, 30\% (w/v) glycerol, 2\% (w/v) SDS, $100 \mathrm{mM}$ Tris-HCl, $\mathrm{pH}$ 8.8) with the addition of $100 \mathrm{mM}$ DTT and subsequently, for $15 \mathrm{~min}$ in fresh buffer supplemented with $0.25 \mathrm{M}$ iodoacetamide. The equilibrated IPG strips were transferred onto $12.5 \%$ SDS acrylamide gels by use of an Ettan SE 600 Ruby Electrophoresis Unit (GE Healthcare, Piscataway, NJ, USA). The proteins on gels were visualized by staining with Coomassie Brilliant Blue dye (CBBR250) (Candiano et al. 2004). Images of CBB-stained gels were acquired at 300 dpi scanning resolution and 16-bit pixel depth, and then were analyzed with ImageMaster 2D Platinum 7.0 software according to protocols provided by the manufacturer (GE Healthcare Life Sciences ${ }^{\circledR}$, PA, USA).

SPOT IDENTIFICATION BY MASS SPECTROMETRY (MS)

In-gel digestion of proteins was performed as described by Shevchenko et al. (2007), with minor modifications. Trypsin was used at a concentration of $25 \mathrm{ng} / \mu \mathrm{L}$ and the reduction and alkylation step was omitted.

Peptides were dissolved in $10 \mu \mathrm{L} \quad 0.1 \%$ trifluoroacetic acid (TFA). A saturated solution of alpha-cyano-4-hydroxycinnamic acid (CHCA, 4 $\mathrm{mg} / \mathrm{mL}$ ) in $50 \%$ acetonitrile and $0.3 \%$ TFA was mixed with an equal amount of sample and spotted on an Anchor Chip 800/384 target plate (Bruker Daltonic $\mathrm{GmbH}$ ). The sample then was dried in a laminar airflow cabinet for recrystallization. For MS calibration, $0.5 \mu \mathrm{L}$ of peptide calibration standard
(Bruker Daltonik GmbH) was spotted on the target plate with $0.8 \mu \mathrm{L}$ of CHCA matrix. Samples were analyzed in a matrix-assisted laser desorption/ ionization (MALDI) time-of-flight (TOF)/TOF mass spectrometer (Ultraflex, Bruker Daltonics, Bremen, Germany) in reflectron mode. Peptides with a signal-to-noise ratio above 100 were MS/ MS analyzed by using the LIFT technology that is embedded in the Ultraflex MS; on average, ten MS/ MS spectra were measured for each protein digest, leading to 2-10 identified peptides. Data were processed using the flex analysis and biotools ${ }^{\mathrm{TM}}$ software packages (Bruker Daltonik).

Data analysis was performed using BioTools 3.0 software and MASCOT search engine (Matrix Sciences, UK). Searches were performed using the following parameters: mass tolerance was set to 0.7 Dafor fragmentions; trypsin wassetas the proteolytic enzyme with one allowed missed cleavage; charge state $1^{+}$was used; carbamidomethylation of cysteine residues was used as a fixed modification; and oxidation of methionine residues was set as a variable modification.

The NCBInr database was used to identify scorpion proteins either with an in-house or online MASCOT server (Matrix Science, UK). Proteins were both identified and denominated if at least two peptides were identified with a MASCOT peptide ion score higher than 75 .

ANIMALS

Male Wistar rats $(n=6)$, weighing 250 to $300 \mathrm{~g}$, were used in the isolated kidney perfusion assay. The animals were fasted with free access to water $12 \mathrm{~h}$ before experimentation. The experimental protocols used in this study were approved previously by the Ethics Committees on Animal Experimentation of the Universidade Federal do Ceará under $n^{\circ} .539 / 13$.

\section{ISOLATED PERFUSED RAT KIDNEY}

For the isolated kidney perfusion assay, the rats were anesthetized with sodium pentobarbital (50 
$\mathrm{mg} / \mathrm{kg}$, i.p.) and after careful dissection of the right kidney, the right renal artery was cannulated via the mesenteric artery without interrupting the blood flow as described by Bowman (1970). The perfusion fluid consisted of a modified Krebs-Henseleit solution (MKHS) of the following composition (in $\mathrm{mmol} / \mathrm{L}$ ): $114.00 \mathrm{NaCl}, 4.96 \mathrm{KCl}, 1.24 \mathrm{KH}_{2} \mathrm{PO}_{4}$, $0.5 \mathrm{MgSO}_{4} .7 \mathrm{H}_{2} \mathrm{O}, 2.10 \mathrm{CaCl}_{2}$, and $24.99 \mathrm{NaHCO}_{3}$. Bovine serum albumin fraction $\mathrm{V}$ (BSA, $6 \mathrm{~g}$ ), urea $(0.075 \mathrm{~g})$, inulin $(0.075 \mathrm{~g})$, and glucose $(0.15 \mathrm{~g})$ were added to the solution, resulting in a final perfusion fluid volume of $100 \mathrm{~mL}$. The $\mathrm{pH}$ was adjusted to 7.4. In each experiment, $100 \mathrm{~mL}$ of MKHS was recirculated for $120 \mathrm{~min}$. The perfusion pressure (PP) was measured at the tip of the stainless steel cannula in the renal artery. Samples of urine and perfusion fluid were collected at 10 min intervals for analysis of the sodium, potassium, and chloride levels by ion-selective electrodes (RAPIDChem 744, Bayer Diagnostic, UK); inulin, as described by Walser et al. (1955) and modified by Fonteles et al. (1983); and osmolality, which was measured in a vapor pressure osmometer (Wescor $5100 \mathrm{C}$, USA). The venom of T. stigmurus (TsV) (0.3 and $1.0 \mu \mathrm{g} / \mathrm{mL}$ ) was added to the system $30 \mathrm{~min}$ after the beginning of each perfusion. The perfusion pressure (PP), renal vascular resistance (RVR), urinary flow (UF), glomerular filtration rate (GFR), the excretion of sodium $\left(\mathrm{ENa}^{+}\right)$, potassium $\left(\mathrm{EK}^{+}\right)$, and chloride $\left(\mathrm{ECl}^{-}\right)$were determined (MartinezMaldonado and Opava-Stitzer 1978). The results were compared with those of the internal control group (the first 30 min of perfusion of each animal) and with those of the external control group (one group perfused only with MKHS for $120 \mathrm{~min}$ ). After each experiment, the kidneys (perfused and non-perfused) were fixed in $10 \%$ buffered formalin, processed, and blocked with paraffin, and then sectioned into $5 \mu \mathrm{m}$ sections. The slides were stained with hematoxylin and eosin (HE) and examined using a light microscope.
DIRECT EFFECT ON MADIN-DARBY CANINE KIDNEY (MDCK) CELLS

Epithelial MDCK cells were cultivated in RPMI 1640 medium supplemented with $10 \%$ fetal bovine serum (FBS), 1\% penicillin (10 $000 \mathrm{IU} / \mathrm{mL})$, and streptomycin $(10 \mathrm{mg} / \mathrm{mL})$. Before each experiment, cells were kept in medium without FBS for $24 \mathrm{~h}$ to obtain cells in the G0 phase of cell cycle. Then, cells were removed and incubated with trypsinEDTA $(0.25 / 0.02 \% \mathrm{v} / \mathrm{v})$ at $37{ }^{\circ} \mathrm{C}$ for about $5 \mathrm{~min}$. After this, the cells were counted in a Neubauer chamber, chamber, suspended in culture medium (1 $\times 10^{5}$ cells) and $24 \mathrm{~h}$ later used for the experiments.

Cell viability was assessed by the 4,5-dimetilazil-2-il)-2,5 diphenyl tetrazolium (MTT) assay as described by Mosmann (1983). The MDCK cells were plated in 96-well plates at a density of $10^{5}$ cells and treated with different concentrations of $\operatorname{TsV}(3.12,6.25,12.5,25,50,100$, and $200 \mu \mathrm{g} / \mathrm{mL})$. After $24 \mathrm{~h}$ of treatment, the cells were incubated with $2.5 \mathrm{mg} / \mathrm{mL}$ MTT for $4 \mathrm{~h}$. The formazan crystals that resulted from MTT reduction were dissolved by adding SDS (10\%) to each well, followed by incubation for $17 \mathrm{~h}$. The absorbance was read at 570 $\mathrm{nm}$ in a microplate reader (Biochrom ${ }^{\circledR}$ Asys Plus), and cell viability was calculated by comparing the resulting absorbances with the mean absorbance of the control wells (without venom, considered to be $100 \%$ viable).

\section{STATISTICAL ANALYSIS}

Data are expressed as mean \pm SEM and were analyzed by ANOVA, followed by the Bonferroni test using GraphPad Prism ${ }^{\circledR} 5.0$ with significance set at $\mathrm{p}<0.05$.

\section{RESULTS}

2D-PAGE AND MASS SPECTROMETRY ANALYSIS

The resolution of $400 \mu \mathrm{g}$ of protein loaded on each gel showed an average of 27 spots with $\mathrm{pI}$ ranging between 3 and 10 and molecular masses ranging 
between 52 and $17 \mathrm{kDa}$ (Figure 1). The proteins were identified via MALDI TOF/TOF (MS/MS) tandem mass spectrometry, which achieved 14\% (4 of 27 spots) successful identifications (Table I). The four identified proteins are isoforms of antarease, a zinc-binding metalloprotease found in venom of $T$. serrulatus.

\section{RENAL EFFECTS OF TsV}

TsV altered all evaluated renal function parameters at a concentration of $1.0 \mu \mathrm{g} / \mathrm{mL}$, increasing perfu- sion pressure (Fig. 2a), renal vascular resistance (Fig. 2b), and urinary flow (Fig. 2c), 10 min after the addition of $\mathrm{TsV}$ to the system. The glomerular filtration rate increased $20 \mathrm{~min}$ after TsV addition (Fig. 2d). The excretion of sodium, potassium and chloride increased significantly at the same concentration $(1.0 \mu \mathrm{g} / \mathrm{mL})$, as shown in Fig. 3, with a consistent increase for the entire duration of experiment. $\mathrm{TsV}$ at a lower concentration $(0.3$ $\mu \mathrm{g} / \mathrm{mL}$ ) had no effect on the evaluated parameters compared to those of the external control group.

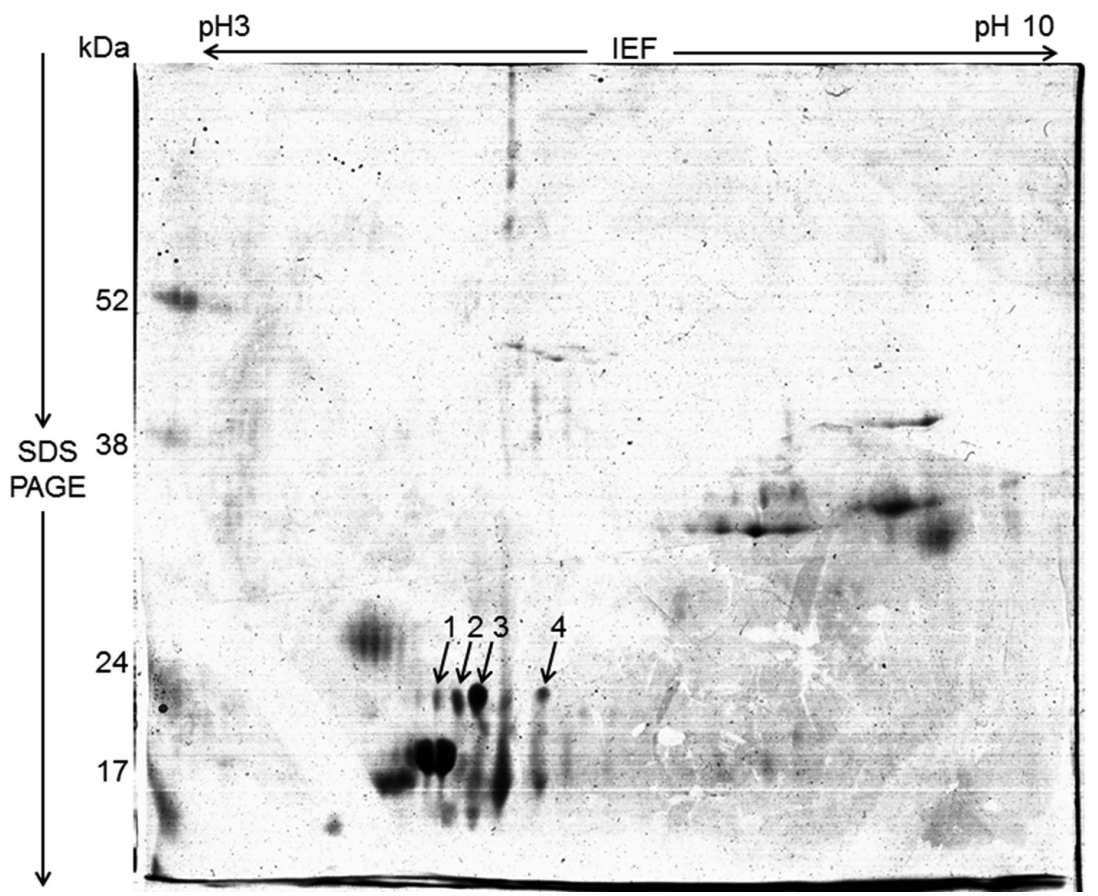

Figure 1 - Proteome profile of Tityus stigmurus venom (TsV) on 2D-PAGE.

TABLE I

List of proteins identified in the venom of Tityus stigmurus by MALDI TOF/TOF.

\begin{tabular}{|c|c|c|c|c|c|c|}
\hline Spot $^{\mathrm{a}}$ & Identity $^{\mathrm{b}}$ & Organism $^{c}$ & Accession $^{\mathrm{d}}$ & Score $^{e}$ & $\mathrm{pI}^{\mathrm{f}}$ & $\mathrm{Mr}^{\mathrm{f}}$ \\
\hline 1 & $\begin{array}{l}\text { Full=Venom metalloproteinase antarease } \\
\text { TserMP_A; Short=VMPA, partial }\end{array}$ & Tityus serrulatus & gi|568818739 & 77 & 5.0 & 25.8 \\
\hline 2 & $\begin{array}{l}\text { Full=Venom metalloproteinase antarease } \\
\text { TserMP_A; Short=VMPA, partial }\end{array}$ & Tityus serrulatus & gi|568818740 & 80 & 5.0 & 25.8 \\
\hline 3 & $\begin{array}{l}\text { Full=Venom metalloproteinase antarease } \\
\text { TserMP_A; Short=VMPA, partial }\end{array}$ & Tityus serrulatus & gi|568818741 & 81 & 5.0 & 25.8 \\
\hline 4 & $\begin{array}{l}\text { Full=Venom metalloproteinase antarease } \\
\text { TserMP_A; Short=VMPA, partial }\end{array}$ & Tityus serrulatus & gi|568818742 & 78 & 5.0 & 25.8 \\
\hline
\end{tabular}

${ }^{a}$ Number allocated according to the numbers used in Figure 1. ${ }^{b}$ Identification of proteins annotated by mass spectrometry. ${ }^{\mathrm{c}}$ Species from which protein was annotated. ${ }^{\mathrm{d}}$ Access number to the database (nrNCBI). ${ }^{\mathrm{e}} \mathrm{MASCOT}$ score. ${ }^{\mathrm{f}}$ Theoretical molecular weight and isoelectric point computed from the calculation tool $\mathrm{Mr} / \mathrm{pI}$ from ExPASy. 

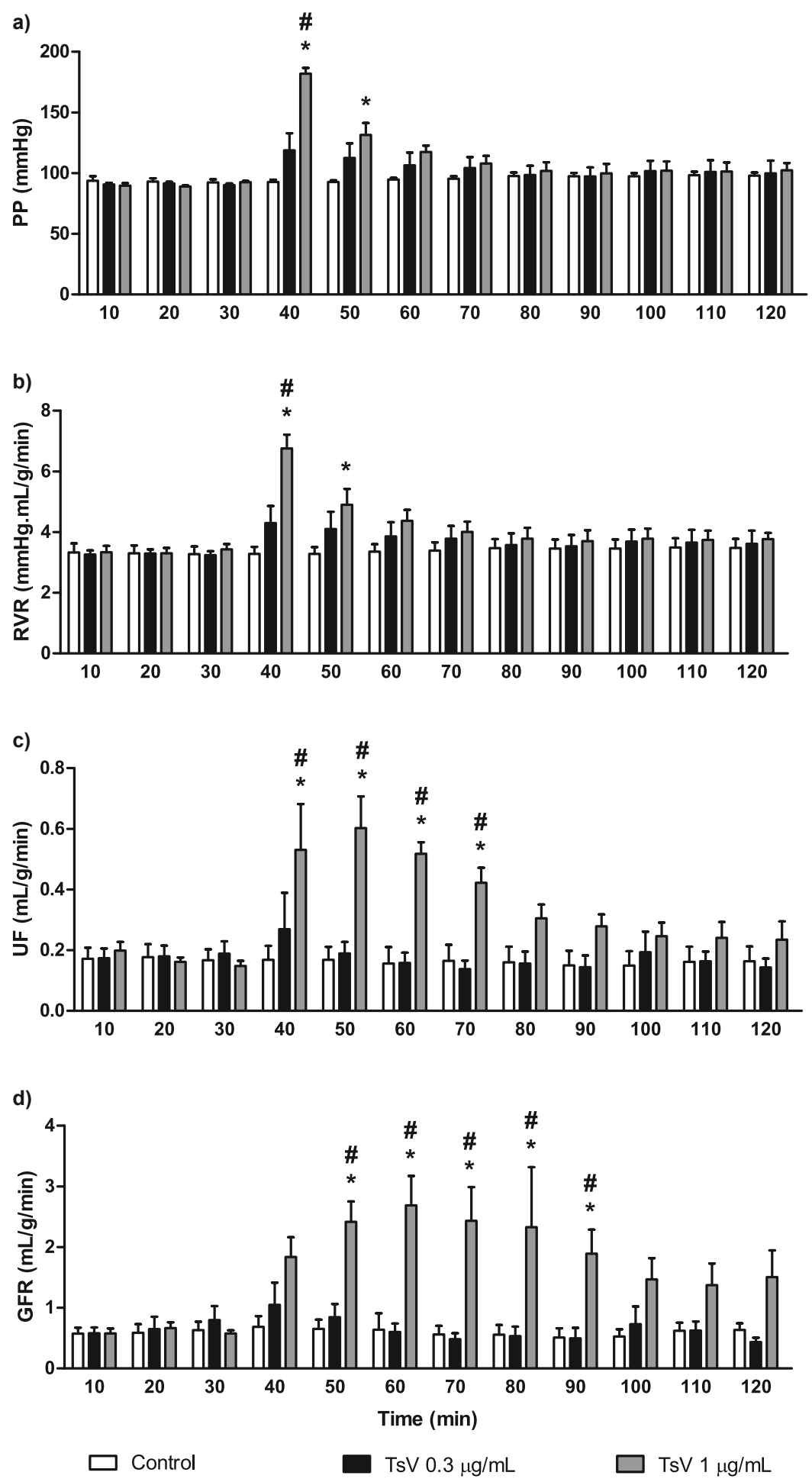

Figure 2 - Effect of Tityus stigmurus venom (TsV) on perfusion pressure (a), renal vascular resistance (b), urinary flow (c), and glomerular filtration rate (d). Data are expressed as mean \pm SEM from six different animals and were analyzed by ANOVA followed by Bonferroni test. ${ }^{*} \mathrm{p}<0.05$ compared with the corresponding external control group for each interval. ${ }^{*} \mathrm{p}<0.05$ compared with the group treated with 0.3 $\mu \mathrm{g} / \mathrm{mL}$ for each interval. 

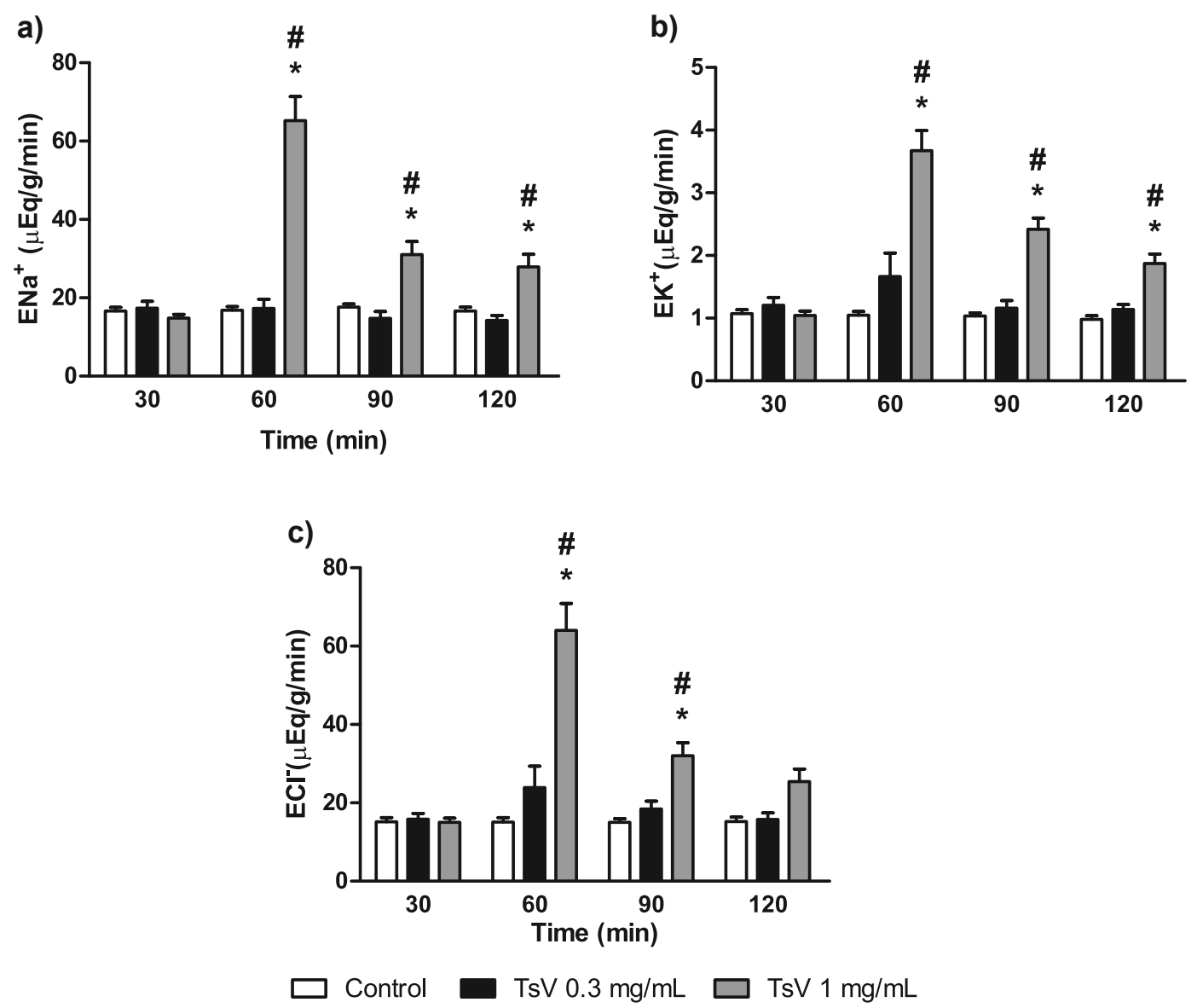

Figure 3 - Effect of Tityus stigmurus venom (TsV) on sodium (a), potassium (b), and chloride (c) excretion. Data are expressed as mean \pm SEM from six different animals and were analyzed by ANOVA followed by Bonferroni test. ${ }^{*} \mathrm{p}<0.05$ compared with the corresponding external control group for each interval. ${ }^{*} \mathrm{p}<0.05$ compared with the group treated with $0.3 \mu \mathrm{g} / \mathrm{mL}$ for each interval.

The histological analysis of the perfused kidneys is shown in Table II. No changes were observed in the glomeruli and tubules of control nonperfused and perfused kidneys, while in both TsV groups, intratubular protein deposits and hydropic degeneration were observed in epithelial tubular cells of the proximal and distal convoluted tubules.

TsV at concentrations up to $200 \mu \mathrm{g} / \mathrm{mL}$ did not show any effect on viability of MDCK cells (Fig. 4).

\section{DISCUSSION}

Animal venoms are complex mixtures of toxins, including proteins, peptides, enzymes, and chemicals (Sitprija 2008). Among the components of scorpion venom are enzymes, nucleotide, lipids, biogenic amines, and peptides. Peptides are important components of scorpion venom and have been classified into several families and subfamilies according their structures and biological effects (Barona et al. 2006). 2D-PAGE analysis of TsV identified four spots of antarease-like proteins, which are ubiquitous to a broad range of scorpion species, including in the venom of several Tityus spp. Antareases are catalytically active enzymes that penetrate intact tissue and cleave vesicleassociated membrane protein 2 (VAMP2), which is involved in pancreatic secretion. These enzymes may be responsible for scorpionism-induced acute pancreatitis (Ortiza et al. 2014). Almeida et al. (2012) completed a venom gland transcriptome 
TABLE II

Qualitative histological analysis of the kidneys perfused with $T$. stigmurus venom (TsV) at 0.3 and $1.0 \mu \mathrm{g} / \mathrm{mL}$.

\begin{tabular}{llc}
\hline Group & Histological changes & Frequency \\
\hline $\begin{array}{l}\text { Control (Kidney not perfused) } \\
\text { External control (Kidney } \\
\text { perfused with MKHS) }\end{array}$ & No changes were observed in glomeruli and tubules. & - \\
& No changes were observed in glomeruli and tubules. & $(6 / 6)$ \\
& Normal glomeruli & $(4 / 6)$ \\
TsV $\mathbf{0 . 3} \mu \mathbf{g} / \mathbf{m L}$ & Small protein deposits in the PCT and DCT & $(1 / 6)$ \\
& Hydropic degeneration in epithelial cells of the PCT and DCT & $(0 / 6)$ \\
& Inflammatory cells infiltrate & $(6 / 6)$ \\
TsV $1.0 \mu \mathrm{g} / \mathbf{m L}$ & Normal glomeruli & $(3 / 6)$ \\
& Small protein deposits in the PCT and DCT & $(0 / 6)$ \\
\hline
\end{tabular}

Note: MKHS - modified Krebs-Henseleit solution; PCT - proximal convoluted tubule; DCT - distal convoluted tubule.

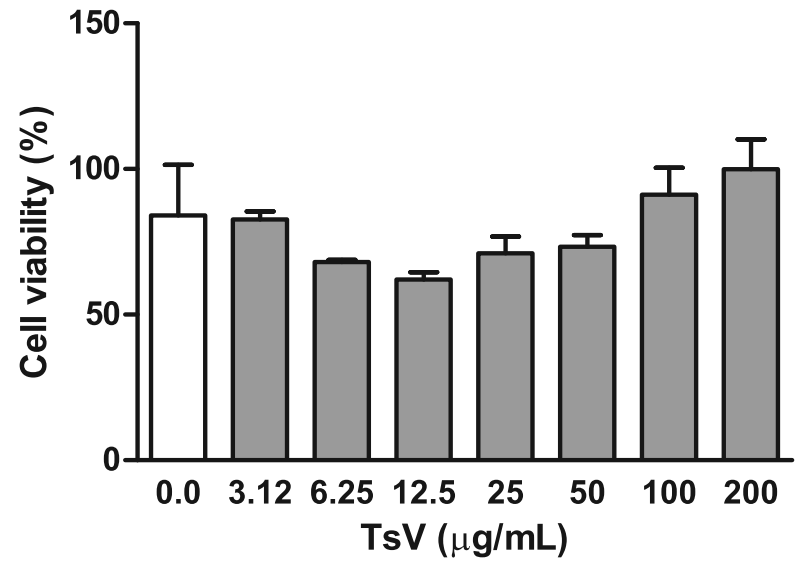

Figure 4 - Effect of Tityus stigmurus venom (TsV) at different concentrations on Madin-Darby Canine Kidney (MDCK) cell viability. Data are expressed as mean \pm SEM of three independent experiments and were analyzed by ANOVA followed by Dunnett's test.

analysis of $T$. stigmurus and found seven transcripts (clones) represented by six clusters encoding metalloproteases, of which four were similar to antareases-like proteins. Despite this, a previous proteome analysis of $T$. stigmurus venom from Mexico did not find antareases-like proteins (Batista et al. 2007).

Many animal venoms, including venoms from snakes (Morais et al. 2013, Suntravat et al. 2011, Mello et al. 2010), spiders (Kusma et al. 2008), bees (Grisotto et al. 2006), wasps (Vinhote et al. 2011), fishes (Faco et al. 2003), sea anemones
(Martins et al. 2009), and scorpions (Alves et al. 2005, Jalali et al. 2011, Heidarpour et al. 2012), can induce renal lesions, mainly acute renal failure. High vascularization, a feature of excretory organs, and the speed at which the scorpion toxins reach the kidneys (at about $15 \mathrm{~min}$ after the sting) are the major factors that lead to vulnerability of the kidneys and the development of nephrotoxicity after scorpion stings (Sitprija 2008, Ismail and Elsalam 1988).

T. stigmurus venom increases the RVR and the PP together with urinary flow, which resembles pressure diuresis and could be owing to the presence of biogenic amines in the venom that cause intrarenal vasoconstriction (Badzyńska and Sadowski 2011). Alves et al. (2005) showed that the venom of $T$. serrulatus also increases PP and RVR, probably owing to the direct vasoactive action of the venom, as demonstrated by the mesenteric bed assay. Their results suggest the effect of venom on $\alpha 1$-adrenoceptors. These receptors are found abundantly in the kidney, in both afferent and efferent arterioles (Angelo et al. 2003).

Nevertheless, the quick return of the PP to the basal values could be explained by (1) the direct lesion of the basal membrane of glomerular capillaries due to the elevated PP (Alves et al. 2005) and/or by (2) the presence of pore formation 
peptides in the venom, as known for other scorpion species (Sitprija and Sitprija 2012). Taken together, these factors could contribute to the increase in the GFR and UF, as well as to the intratubular protein deposits in the proximal and distal convoluted tubules as observed in the histological analysis.

The hydropic degeneration of epithelial cell of the proximal and distal convoluted tubules implies direct tubular injury. Sitprija (2008) implicated tubular necrosis as the main pathological alteration due to scorpion poisoning. This kind of lesion reinforces the increase in urinary flow and intensifies diuresis, as well as contributes to the decrease in electrolyte reabsorption, with an augmentation of sodium, potassium, and chloride excretion.

The renal tubular transport of electrolytes, especially $\mathrm{Na}^{+}$and $\mathrm{K}^{+}$, usually are affected by animal toxins. Tubular reabsorption of $\mathrm{Na}^{+}$is inhibited by most animal toxins as shown in isolated renal perfusion studies, resulting in an augmented $\mathrm{Na}^{+}$excretion. The exact site in the renal tubule where inhibition occurs has not been elucidated yet (Sitprija and Sitprija 2012). Scorpion toxins, such as charybdotoxin from Leiurus quinquestriatus hebraeus and iberiotoxin from Hottentota tumulus, decrease $\mathrm{K}^{+}$transport to the tubular lumen (Harvey et al. 1994). However, blocking of calcium-activated $\mathrm{K}^{+}$channels (Maxi-K) in the collecting ducts by scorpion toxins can cause clinical hyperkalemia through decreased $\mathrm{K}^{+}$secretion in the cortical connecting duct (Sitprija and Sitprija 2012, Ismail et al. 1978).

In addition to the effects on $\mathrm{K}^{+}$channels, scorpion toxins in general also affect $\mathrm{Na}^{+}$and $\mathrm{Cl}^{-}$channels, while T. serrulatus toxins are well known for opening $\mathrm{Ca}^{2+}$ channels (Sitprija and Sitprija 2012), which could contribute to the increase in RVR and $\mathrm{PP}$, and also could participate in the tubular injury due to the deleterious consequences of increased cytosolic $\mathrm{Ca}^{2+}$ concentration (Duchen 2000).

In conclusion, $T$. stigmurus venom induces a transient elevation of renal perfusion pressure, with mild glomerular injury and moderate direct tubular lesion, which leads to increased urinary flow, with elevation of sodium, potassium and chloride excretion. No direct cytotoxicity on MDCK cells was observed at concentrations up to $200 \mu \mathrm{g} / \mathrm{mL}$. Protein analysis by gel electrophoresis (2D-PAGE) revealed the presence of four antarease-like proteins.

\section{ACKNOWLEDGMENTS}

The authors wish to thank Silvia Helena for technical support. Authors would also like thank Conselho Nacional de Desenvolvimento Científico e Tecnológico (CNPq) and Coordenação de Aperfeiçoamento de Pessoal de Nível Superior (CAPES) for financial support and fellowships. The language of this text was revised by Editage.

\section{RESUMO}

Os escorpiões de interesse médico no Brasil pertencem ao gênero Tityus. Dentre eles, Tityus stigmurus é o principal responsável por picadas de escorpião na região Nordeste. Após uma picada, a peçonha de escorpião se distribui rapidamente para os órgãos, atingindo os rins depressa. Entretanto, há poucos trabalhos sobre fisiopatologia renal do envenenamento por escorpiões. Neste trabalho, avaliamos os efeitos da peçonha de T. stigmurus (TsV) sobre parâmetros renais em rins de ratos isolados. Ratos Wistar $(\mathrm{n}=6)$, pesando 250-300 g, foram perfundidos com solução de Krebs-Henseleit contendo 6 g/100 mL de albumina de soro bovino. TsV nas concentrações de 0,3 e $1,0 \mu \mathrm{g} / \mathrm{mL}$ foi testado e os efeitos sobre a pressão de perfusão (PP), resistência vascular renal (RVR), fluxo urinário (FU), taxa de filtração glomerular (TFG) e excreção de eletrólitos foram analisados. Apenas na concentração de $1,0 \mu \mathrm{g} / \mathrm{mL}$ de $\mathrm{TsV}$ foram observados efeitos que aumentaram $\mathrm{PP}\left({ }_{\text {controle }} \mathrm{PP}_{40^{\prime}}=92,7 \pm 1,95\right.$; $\left.{ }_{\mathrm{TsV}} \mathrm{PP}_{40}=182,0 \pm 4,70 \mathrm{mmHg} *, * \mathrm{p}<0,05\right), \mathrm{RVR}$ $\left(_{\text {controle }} \mathrm{RVR}_{40^{\prime}}=3,28 \pm 0,23 \mathrm{mmHg} ;{ }_{\mathrm{Tst}} \mathrm{RVR}_{40}=6,76 \pm\right.$ $\left.0,45 \mathrm{mmHg}^{*},{ }^{*} \mathrm{p}<0,05\right), \mathrm{FU}\left(_{\text {controle }} \mathrm{FU}_{50}=0,16 \pm 0,04\right.$; $\left.{ }_{\text {Tst }} \mathrm{FU}_{50},=0,60 \pm 0,10 \mathrm{~mL} / \mathrm{g} / \mathrm{min}^{*}, * \mathrm{p}<0,05\right)$, a TFG e excreção de eletrólitos, com alterações histológicas que indicam de lesão renal tubular. Em conclusão, peçonha 
de T. stigmurus induz um aumento transiente da PP com lesão tubular, ambos os quais conduzem a uma excreção elevada de eletrólitos.

Palavras-chave: 2D-PAGE, rim, MDCK, veneno, Tityus stigmurus.

\section{REFERENCES}

ABroug F, AYARi M, NOUIRA S, GAMra H, BOUJdARIA R, Elatrous S, BEN FARHAT M AND BOUCHOUCHA S. 1995. Assessment of left ventricular function in severe scorpion envenomation: combined hemodynamic and echo-Doppler study. Intensive Care Med 21(8): 629-635.

ALMEIDA DD, SCORTECCI KC, KOBASHI LS, AGNEZ-LIMA LF, MEDEIROS SR, SILVA-JUNIOR AA, JUNQUEIRADE-AZEVEDo IL AND FERNANDES-PEDRosA MF. 2012. Profiling the resting venom gland of the scorpion Tityus stigmurus through a transcriptomic survey. BMC Genomics 13: 362-373.

ALVES RS ET AL. 2005. Renal effects and vascular reactivity induced by Tityus serrulatus venom. Toxicon 46(3): 271276.

ANGELO K, KOROLKOVA YV, GRUNNET M, GRISHIN EV, PluZhNiKov KA, KLAERKE DA, KNAUS HG, Møller M AND OLESEN SP. 2003. A radiolabeled peptide ligand of the hERG channel, [125I]-BeKm-1. Pflugers Arch 447(1): 55-63.

BADZYŃSKA B AND SADOWSKI J. 2011. Moderate intrarenal vasoconstriction after high pressor doses of norepinephrine in the rat: comparison with effects of angiotensin II. Kidney Blood Press Res 34(5): 307-310.

BARONA J, BATISTA CVF, ZAMUDIO FZ, GÓMEZ-LAGUNAS F, WANke E, Otero R AND POSSANi LD. 2006. Proteomic analysis of the venom and characterization of toxins specific for $\mathrm{Na}^{+}$- and $\mathrm{K}^{+}$-channels from the Colombian scorpion Tityus pachyurus. Biochim Biophys Acta 1764(1): 76-84.

BATISTA CV, ROMÁN-GONZÁlEZ SA, SALAS-CASTILLO SP, ZAMUdio FZ, GÓMEZ-LAGUNAS F AND POSSANI LD. 2007. Proteomic analysis of the venom from the scorpion Tityus stigmurus: biochemical and physiological comparison with other Tityus species. Comp Biochem Physiol C Toxicol Pharmacol 146(1-2): 147-157.

BERGER M, VIEIRA MAR AND GUIMARÃES JA. 2012. Acute Kidney Injury Induced by Snake and Arthropod Venoms. In: Renal Failure - The Facts, InTech, p. 157-186.

BOWMAN RH. 1970. Gluconeogenesis in the isolated perfused rat kidney. J Biol Chem 245: 1604-1612.

BRASIL. 2012. Portal da Saúde. Acesso em 10/11/12. Disponível em: http://portal.saude.gov.br/portal/saude/ profissional/visualizar_texto.cfm?idtxt=31510.
BRASIL. 2014. Ministério da Saúde: casos de acidentes por escorpiões. Acesso em: 10/07/14. Disponível em: http://portalsaude.saude.gov.br/images/pdf/2014/ julho/10/Tabela-09---CASOS---escorpiao--2000-a-2013---21-05-2014.pdf.

Candiano G, Bruschi M, Musante L, Santucci L, GHIGGERI GM, CARNEMOLla B, ORECCHIA P, ZARDI L AND RIGHETTI PG. 2004. Blue silver: a very sensitive colloidal Coomassie G-250 staining for proteome analysis. Electrophoresis 25: 1327-1333.

CHIPPAUX JP AND GOYFFON M. 2008. Epidemiology of scorpionism: a global apprasial. Acta Trop 107: 71-79.

DEHGHANI R AND FATHI B. 2012. Scorpion sting in Iran: A review. Toxicon 60: 919-933.

DUCHEN MR. 2000. Mitochondria and calcium: from cell signalling to cell death. J Physiol 529(1): 57-68.

FACO PEG, HAVT A, BARBOSA PSF, NOBRE ACL, BEZERRA GP, MENEZES DB, FONTELES MC, LOPES-FERREIRA M AND MONTEIRO HAS. 2003. Effects of Thalassophryne nattereri fish venom in isolated perfused rat kidney. Toxicon 42: 509-514.

FONTELES MC, COHEN JJ, BLACK AJ AND WERTHEIM SJ. 1983. Support of renal kidney function by long-chain fatty acids derived from renal tissue. Am J Physiol 244(3): F235-246.

FUndAÇÃO NACIONAL DE SAÚdE. 2001. Manual de Diagnóstico e tratamento de acidentes por animais peçonhentos. Gerência Técnica da Coordenação e Comunicação, Educação e Documentação. Ministério da Saúde, Brasília. GrisotTo LSD, MENDES GE, CASTRO I, BAPTISTA MASF, ALVES VA, YU L AND BURDMANN EA. 2006. Mechanisms of bee venom-induced acute renal failure. Toxicon 48: 44-54.

GWEEMCE,NIRTHANANS, KHOOHE, GOPALAKRISHNAKONE P, KINI RM AND CHEAH LS. 2002. Autonomic effects of some scorpion venoms and toxins. Clin Exp Pharmacol Physiol 29(9): 795-801.

HARVEY AL, ROWAN EG, VATANPOUR H, FATEHI M, Castaneda O And Karlsson E. 1994. Potassium channel toxins and transmitter release. Ann NY Acad Sci 710: $1-10$.

HEIDARPOUR M ET AL. 2012. Histopathological changes induced by Hemiscorpius lepturus scorpion venom in mice. Toxicon 59(3): 373-378.

ISMAIL M AND ELSALAM A. 1988. Are the toxicological effects of scorpion envenomation related to tissue venom conventration? Toxicon 26: 233-236.

ISMAIL M, GUMAA KA, OSMAN OH AND EL-ASMAR MF. 1978. Effect of Buthus minax (L. Koch) scorpion venom on plasma and urinary electrolyte levels. Toxicon 16: 385-392.

JALALI A, PIPELZADEH MH, SEYEDiAn R, RAHMANI AH AND OMIDIAN N. 2011. In vivo pharmacological study on the effectiveness of available polyclonal antivenom against Hemiscorpius lepturus venom. J Venom Anim Toxins incl Trop Dis 17(2): 142-149. 
Kusma J, Chaim OM, Wille ACM, Ferrer VP, SADE YB, DONATTI L, GREMSKI W, MANGILI OC AND VEIGA SS. 2008. Nephrotoxicity caused by brown spider venom phospholipase-D (dermonecrotic toxin) depends on catalytic activity. Biochimie 90: 1722-1736.

MARTINEZ-MALDONADO M AND OPAVA-STITZER R. 1978. Free water clearance curves during saline, mannitol, glucose and urea diuresis in the rat. J Physiol 280: 487497.

MARTINS AMC, BARbosa PSF, SOUSA DF, Alves CD, MENEZES DB, LiMA C, LOPES-FERREIRA M, FONTELES MC AND MONTEIRO HSA. 2009. Antivenom action on renal effects induced by Thalassophryne nattereri venom. J Venom Anim Toxins incl Trop Dis 15(1): 125-135.

MAZZEI DE D'AVILA CA, D'AVILA DF, DONIS JH, BELlabARBA GA, VILlARREAL V AND BARBOZA JS. 2002. Sympathetic nervous system activation, antivenin administration and cardiovascular manifestations of scorpion envenomation. Toxicon 40: 1339-1346.

Mello SM, LinARdi A, RENNó AL, TARSitANo CAB, PEREIRA EM AND HYSLOP S. 2010. Renal kinetics of Bothrops alternatus (Urutu) snake venom in rats. Toxicon 55: 470-480.

MORAIS ICO ET AL. 2013. Bothrops leucurus venom induces nephrotoxicity in the isolated perfused kidney and cultured renal tubular epithelia. Toxicon 61: 38-46.

MOSMANN T. 1983. Rapid colorimetric assay for cellular growth and survival application to proliferation and cytotoxicity assays. J Immunol Methods 65: 55-63.

NAQVI R, NAQVI A, AKHTAR F AND RIZVI A. 1998. Acute renal failure developing after a scorpion sting. Br J Urol 82: 295.

NunAN EA, MORAES MFD, CARDOSO VN AND MORAESSANTOS T. 2003. Effect of age on body distribution of tityustoxin from Tityus serrulatus scorpion venom in rats. Life Sci 73: 319-325.

ORTIZA E, RENDÓN-ANAYA M, REGO SC, SCHWARTZ EF AND POSSANI LD. 2014. Antarease-like Zn-metalloproteases are ubiquitous in the venom of different scorpion genera. Biochim Biophys Acta 1840(6): 1738-1746.

POSSANI LD. 1984. Structure of scorpion toxins. In Handbook of Natural Toxins [Tu AT (Ed)], Marcel Dekker, Inc., New York 2: 513-550.
POSSANi LD, BECERril B, DELEPIERRE M AND TYTGAT J. 1999. Scorpion toxin specific for Na-channels. Eur J Biochem 264: 287-300.

Rodriguez DE LA VEGA RC AND POSSANI LD. 2005. Overview of scorpion toxins specific for $\mathrm{Na}+$ channels and related peptides: biodiversity, structure-function relationships and evolution. Toxicon 46: 831-844.

SheVCHENKO A, TOMAS H, HAVlis J, OlsEN JV AND MANN M. 2007. In-gel digestion for mass spectrometric characterization of proteins and proteomes. Nature Protocols 1: 2856-2860.

SitpriJA V. 2008. Animal toxins and the kidney. Nat Clin Pract Nephrol 4: 616-627.

SITPRIJA V AND SITPRIJA S. 2012. Renal effects and injury induced by animal toxins. Toxicon 60: 943-953.

Suntravat M, YusuKSAWAD M, SEREEMASPun A, PÉREZ JC AND NUCHPRAYOON I. 2011. Effect of purified Russell's viper venom-factor $\mathrm{X}$ activator (RVV-X) on renal hemodynamics, renal functions, and coagulopathy in rats. Toxicon 58: 230-238.

VALAVI E AND ANSARI MJ. 2008. Hemolytic uremic syndrome following Hemiscorpius lepturus (scorpion) sting. Indian J Nephrol 18: 166-168.

VASCONCELOS F, LANCHOTE VL, BENDHACK LM, GIGLIO JR, SAMPAIO SV AND ARANTES EC. Effects of voltagegated $\mathrm{Na}^{+}$channel toxins from Tityus serrulatus venom on rat arterial blood pressure and plasma catecholamines. Comp Biochem Physiol C Toxicol Pharmacol 141(1): 8592.

VINHOTE JFC ET AL. 2011. Renal- and calcium-dependent vascular effects of Polybia paulista wasp venom. J Venom Anim Toxins incl Trop Dis 17: 199-208.

VISWANATHAN S AND PRABHU C. 2011. Scorpion sting nephropathy. NDT Plus 4: 376-382.

WALSER M, DAVIDSON DG AND ORLOFF J. 1955. The renal clearance of alkali stable inulin. J Clin Invest 34: 15201523.

Zeghal K, Souhir S, Guinot M, Richer C AND GIUDICELLI JF. 2000. Charecterization and mechanisms of the cardiovascular and haemodynamic alterations induced by scorpion venom in rats. Fundam Clin Pharmcol 14: 351-361. 